\title{
Effects of Partial Substitution of Fishmeal by \\ Crustacean (Callianassa) Meal on the Growth \\ Performance, Feed Efficiency and Survival Rate of Nile Tilapia (Oreochromis niloticus)
}

Sokhna Khady Lo Fall, Jean Fall (Corresponding author), Abdoulaye Loum, Mariama Sagne Institut Universitaire de Pêche et d'Aquaculture, UCADII Bâtiment Pédagogique, Rez de chaussée, BP: 5005. E-mail: kagoshima77@yahoo.com

Saloum Jatta

Department of Fisheries, 6, Marina Parade, Banjul, The Gambia

\section{Diegane Ndong}

Direction des Ressources Animales et Halieutiques, Département de l'Agriculture, des Ressources en Eau et de l'Environnement, Commission de l'UEMOA, 380 Av. Pr. Joseph KI-ZERBO, 01 BP 543 Ouagadougou 01-Burkina Faso.

Malick Diouf

Institut Universitaire de Pêche et d'Aquaculture, UCADII Bâtiment Pédagogique, Rez de chaussée, BP: 5005

Shyn Shin Sheen

Department of Aquaculture, National Taiwan Ocean University, Keelung, 20224, Taiwan, ROC

Received: Feb. 3, $2020 \quad$ Accepted: Mar. 2, 2020

doi:10.5296/jbls.v11i1.16700 URL: https://doi.org/10.5296/jbls.v11i1.16700 


\section{Abstract}

The effect of substituting fishmeal with crustacean (Callianassa) meal in the diets of mixed sex Nile tilapia (Oreochromis niloticus) fry $(0.2 \mathrm{~g})$ was evaluated. Three isonitrogenous and isolipidic diets were formulated to contain $30 \% \mathrm{CP}$ and $15 \% \mathrm{CL}$ where fishmeal was substituted with Callianassa meal at 0,25 and $50 \%$ in diets R1, R2 and R3 respectively. The experiment lasted for 6 weeks. The stocking density was 10 fish per tank in an isolated system and the capacity of each tank was 50L. Each treatment was administered in duplicates and fish were fed three times per day $(09 \mathrm{~h}, 13 \mathrm{~h}$, and $17 \mathrm{~h})$. The daily ration corresponds to $10 \%$ of the live weight of the fish during the first 2 weeks and was reduced to $8 \%$ and then $6 \%$ for the second and last two weeks of the trial period. At the end of the experiment, fish fed on R1 (control) diet and R2 diet (25\% fishmeal replacement) had similar final weight $(0.62 \mathrm{~g})$, absolute mean weight gain $(0.42 \mathrm{~g})$, relative mean weight gain $(210 \%)$ and specific growth rate $(2.50 \%)$ and were significantly different from the values obtained from those fed on R3 diet (50\% fishmeal replacement). R3 diet had the best FCR (1.42) and was significantly different from the values obtained from R1 and R2 diets but the values of the diets were not significantly different. The dry matter content of the initial fish $(96.33 \%)$ and those of the R1 $(94.12 \%)$ and R2 $(95.71 \%)$ diets did not differ significantly but were slightly higher than that of the value obtained from fish fed on R3 diet (91.15). The protein content of the initial fish (49.63\%) was significantly lower than the values obtained from fish fed on R3 diet $(61.95 \%)$, R1 diet $(54.74 \%)$ and $\mathrm{R} 2$ diet $(52.59 \%)$. The fat content of the initial fish $(41.51 \%)$ was higher than the values obtained when fish were fed on the experimental diets. Among the tested diets, the higher the crustacean meal in the diet, the lower the fat content of the fish muscle. The fat content of R1 (control) diet (29.56\%) was slightly higher than the value of R3 diet (24.44\%) and slightly lower than R2 diet (32.56\%). It is concluded that crustacean meal can replace $25 \%$ of fishmeal in the diet of Nile tilapia (Oreochromis niloticus) fry at $0.2 \mathrm{~g}$ without any effect on the growth performances and feed efficiency.

Keywords: fishmeal, substitution, Oreochromis niloticus, crustacean meal, growth and muscle composition

\section{Introduction}

The strong demographic growth is increasing the demand for fishery products, a large part of which is provided by capture fisheries. At the moment, the productivity of this sector is declining because most of the fish stocks are either over-exploited or fully exploited and only a few stocks are under-exploited. Declining catches is characterizing the current situation of scarcity of fish in the world.

Therefore, aquaculture is considered to be the sector capable of increasing fish production and animal protein intake for the ever-growing population. The world production of farmed fish for human consumption has been remarkably increasing and stood at 73.8 million tons in 2014 while in 1960, it was just 1.6 million tons (FAO, 2016). The pivotal role aquaculture is playing in supplying fish to the market during these decades has made it to be considered as one of the most highly productive animal producing activities. The 73.8 million tons produced by aquaculture in 2014 was estimated at US $\$ 160.2$ billion at first sale which 
included 49.8 million tons of fish (US\$ 99.2 billion), 16.1 million tons of shellfish (US \$ 19 billion), 6.9 million tons of crustaceans (US \$ 36.2 billion), and 7.3 million tons of other aquatic animals (3.7 billion US \$) (FAO, 2016). Per capita fish consumption has increased from $10 \mathrm{~kg}$ in the $1960 \mathrm{~s}$ to $19.7 \mathrm{~kg}$ in 2013 (FAO, 2016). The sustainable development of aquaculture requires easy access to quality and efficient feed. The growth of aquaculture worldwide is attributed to the increasing use of compound feeds whose protein component is provided mainly by fishmeal. Considering the development of aquaculture and the foreseeable stagnation of pelagic fishmeal production, it is necessary to reduce the proportion of fishmeal in aqua-feeds. Thus, alternatives to fishmeal such as crustacean meal among others are being studied.

The crustacean used in the formulation of the tested feeds has not been identified. Nevertheless, it belongs to the infra-order of Thalassinidea, in the group of decapod crustaceans (Acad, 1973). Some studies have been conducted to use shrimp meal as partial or total protein source for tilapia. El-Sayed (1998) reported that shrimp meal (SM) could totally replace fishmeal in test diets for Nile tilapia. Plascencia-Jatomea et al. (2002) demonstrated that shrimp head hydrolysate is a promising alternative protein source for tilapia feeding, improving growth ratio at dietary inclusion levels as high as 15\%. Fall et al. (2012) reported that fish fed diet containing shrimp meal (SM) gained weight slightly less than those fed diet containing fishmeal. Diop et al. (2013) revealed that the incorporation of shrimp by-products in the diets of tilapia at $45 \%$ gave the best weight gain (4.96 g) compared to the control diet. Several authors (Jung et al., 2006; Wenhong et al., 2008; Uno et al., 2010; Laila et al., 2010) have highlighted that there exist three methods of waste utilization from aquaculture or wild stocks, which are fishmeal, silage and organic fertilizer productions. The crustacean waste (shrimp, Antarctic Krill, crab and lobster processing) is the most important chitin source. It is present in amounts varying from trace quantities up to about $40 \%$ of the body weight of the organism. Chitin present in the crustacean waste is associated with proteins, minerals (mainly calcium carbonate) and lipids including pigments.

The objective of this study was to evaluate the effects of the partial substitution of fishmeal by crustacean meal on the growth performance of tilapia (Oreochromis niloticus).

\section{Material and Methods}

\subsection{Feed Preparation}

Three isonitrogenous (30\% protein) and isolipidic (15\% lipid) practical diets were formulated in which fishmeal component of the diet was replaced by crustacean meal at $0 \%$ (R1), $25 \%$ (R2) and 50\% (R3). Other ingredients were dried mango peel meal, peanut cake meal, dried mango kernel meal, minerals, and vitamins. Corchorus tridens was used as a natural binder. The composition of the experimental diets is shown in Table 1. For the production of each diet, the raw materials were ground, weighed and mixed with the vitamins, minerals then fish oil and water at $30 \%$ of the diet weight were added to obtain a homogeneous mixture. The paste was passed through an electric chopper machine (Moulinex) with appropriate die to produce spaghetti like filaments of feed. The feeds were then dried under the sun, crushed, and sieved before being put into bags and stored until use. 
Table 1. Formulation of the experimental diets

\begin{tabular}{lccc}
\hline Ingredients (g/kg) & $\mathrm{R} 1(0 \%)$ & $\mathrm{R} 2(25 \%)$ & $\mathrm{R} 3(50 \%)$ \\
\hline Mango kernel meal (g) & 200 & 200 & 200 \\
Mango peel meal (g) & 150 & 140 & 140 \\
Corchorus tridens (g) & 20 & 20 & 20 \\
Crustacean meal (g) & 0 & 42.5 & 85 \\
Fishmeal (g) & 170 & 127.5 & 85 \\
Fish oil (g) & 50 & 50 & 50 \\
Peanut cake meal (g) & 390 & 400 & 400 \\
Vitamines a (g) & 10 & 10 & 10 \\
Minerals b (g) & 10 & 10 & 10 \\
Total & 1000 & 1000 & 1000 \\
\hline
\end{tabular}

a Vit A 250000 UI; Vit D 250000 UI; Vit E 5000 mg;Vit B 100 mg; Vit B 400 mg; Niacine 1000 mg; Pantothenate Ca 2000 mg; Vit B6 300 mg; Vit K3 1000 g ; Vit C 5000 mg; Biotine $15 \mathrm{mg}$; Choline $100 \mathrm{~g}$; BHT $1000 \mathrm{mg}$;

${ }^{b}$ Phosphorus 7\%; Calcium 17\%; Sodium 1.5\%; Potassium 4.6\%; Magnesium 7.5\%; Manganese 738 mg; Zinc 3000 mg; Iron 4000 mg; Copper 750 mg; Iodine 5 mg; Cobalt 208 $\mathrm{mg}$; Calcium and grounded attapulgite qs $1000 \mathrm{~g}$; Fluoride $1.5 \%$.

\subsection{Experimental Fish and System}

Mixed sex tilapia fry obtained by artificial propagation from Ouakam aquaculture station (west coast of Dakar, Senegal) were used. The fry were fed with commercial feed imported from Ghana (Raanan Fish feed company) up to three weeks old. Then the fish were acclimatized for two weeks given the same imported feed three times per day $(9 \mathrm{~h}, 13 \mathrm{~h}$, and 17h). The experiment lasted for 6 weeks. The fry of $0.2 \mathrm{~g}$ average size were randomly distributed in 6 tanks with a stocking density of 10 fish per tank. Each diet was tested in duplicate. The daily ration corresponds to $10 \%$ of the live weight of the fish during the first 2 weeks. For the rest of the experiment, the ration was reduced to $8 \%$ and then to $6 \%$ according to the live weight of the fish after weighing. Fish were hand fed 3 times per day $(09 \mathrm{~h}, 13 \mathrm{~h}$, and $17 \mathrm{~h}$ ). The tanks were cleaned twice a day by siphoning suspended particles and those deposited at the bottom. The fish were subjected to a photoperiod of 12 hours of light and 12 hours of darkness. Physicochemical parameters (temperature, $\mathrm{pH}$ ) were measured daily using an YSI (Yellow Springs Instruments, Yellow Springs, OH, USA), Model 58 meter. Every two weeks, measures of growth parameters (WG, SGR), feed efficiency (FCR) and survival rate (SR) were taken to assess the nutritional quality of diets and the amount of feed given was readjusted. At the end of the experiment, 5 fish are taken at random in each tank and subjected to bromatological carcass analysis.

\subsection{Proximate Analysis of Fish Flesh}

Bromatological analysis of the fish (before and after the experiment) was carried out according to the standard methods of the Association of Official Analytical Chemists (AOAC, 1984). The samples were analyzed at ENSA laboratory in Thiès region, Senegal for 


\section{Macrothink

determination of proximate composition of fish (crude protein, crude fat and dry matter). Fish samples were dried to constant weight at $105^{\circ} \mathrm{C}$ for $24 \mathrm{~h}$ to determine moisture. Crude protein (total Nitrogen x 6.25) was determined by using micro-Kjeldahl method (Kjeltec System 1002 Distilling Unit, Tecator, Hoeganaes, Sweden). Crude fat was extracted by Soxhlet method.

\subsection{Data Calculation and Statistical Analysis}

To estimate growth of fish and characterize the efficiency of the use of experimental diets, different growth parameters were calculated. The growth and feed utilization performance parameters measured were: final mean weight (FMW), absolute mean weight gain (AMWG), relative mean weight gain (RMWG), specific growth rate (SGR) and feed conversion ratio (FCR).

The formulae used in calculations were:

Absolute mean weight gain $(A M W G(g))=$ final mean weight - initial mean weight

Relative mean weight gain $($ RMWG $(\%))=100 \times($ final mean weight - initial mean weight $)$ / initial mean weight.

Specific growth rate $(\operatorname{SGR}(\% / d))=100$ (ln (final mean weight) - ln (initial mean weight)) / number of days.

Feed conversion ratio $(\mathrm{FCR})=$ total dry feed fed $(\mathrm{g}) /$ total wet weight gain $(\mathrm{g})$.

The data were analyzed using SAS software program for windows (V.9 SAS Institute, Cary, North Carolina, USA) and the results were presented as means of the two replicates after subjecting them to one-way analysis of variance (ANOVA) using GLM procedure. In case of significant differences, Duncan's multiple-range test was conducted and the difference was considered significant at $P$-values $<0.05$.

\section{Results and Discussion}

\subsection{Results}

During the experiment, there were no pathological signs or symptoms. The fish accepted the diets. The survival of the fish fed on experimental diets ranged from 50 to $90 \%$. The average temperature ranged between 27.5 and $27.8{ }^{\circ} \mathrm{C}$ whereas $\mathrm{pH}$ values were between 8.74 and 8.75 , both were within the tolerant limits of Nile tilapia (Oreochromis niloticus). 
Table 2. Growth and feed efficiency parameters.

\section{Diets}

\section{Parameters}
R1 (0\%)
R2 (25\%)
R3 (50\%)

IMW (g)

0.2

0.2

0.2

FMW (g)

0.62

0.62

0.56

AMWG (g)

$0.42^{\mathrm{a}}$

$0.42^{\mathrm{a}}$

$0.36^{\mathrm{b}}$

RMWG (\%)

$210^{\mathrm{a}}$

$210^{\mathrm{a}}$

$180^{\mathrm{b}}$

SGR (\%/d)

$2.50^{\mathrm{a}}$

$2.50^{\mathrm{a}}$

$2.29^{\mathrm{b}}$

FCR

$$
2.84^{\mathrm{b}}
$$

$2.93^{\mathrm{b}}$

$1.42^{\mathrm{a}}$

SR (\%)

90

85

50

Values are means of the duplicates; values within the same row without a common superscript are significantly different $(p<0.05)$.

$\boldsymbol{I M W}=$ initial mean weight $; \boldsymbol{F M} \boldsymbol{W}=$ final mean weight; $\boldsymbol{A M W G}=$ absolute mean weight gain; $\boldsymbol{R M W G}(\%)=$ relative mean weight gain; $\mathbf{S G R}(\% / d)=$ specific growth rate; $F C R=$ feed conversion ratio; $\boldsymbol{S} \boldsymbol{R}=$ survival rate.

Table 2 shows the parameters of growth (absolute mean weight gain, relative mean weight gain, specific growth rate), feed efficiency performance (feed conversion ratio), and the survival of tilapia.

The fish fed with R1 diet (control) and R2 diet (25\% crustacean meal replacement for fishmeal) had similar and better final weight $(0.62 \mathrm{~g})$, absolute mean weight gain $(0.42 \mathrm{~g})$, relative mean weight gain $(210 \%)$, specific growth rate $(2.50 \%)$ compared to those fed with $\mathrm{R} 3$ diet (50\% crustacean meal replacement for fishmeal) which are $0.56 \mathrm{~g}, 0.36 \mathrm{~g}, 180 \%$, $2.29 \%$ respectively.

For the feed conversion ratio (FCR), the lowest value (1.42) was obtained from fish fed on $\mathrm{R} 3$ diet and it was significantly different from the values obtained with $\mathrm{R} 1$ and $\mathrm{R} 2$ diets. The fish fed on R1 and R2 diets had higher FCR of 2.84 and 2.93 respectively but there was no significant difference between the two.

The bromatological composition of the flesh of fish 
Table 3. Results of the biochemical analysis of the flesh of $O$. niloticus.

\begin{tabular}{lccc}
\hline & Dry Matter (\%) & Protein (\%) & Lipid (\%) \\
\hline Initial fish & 96.33 & 49.63 & 41.51 \\
R1 (0\%) & 94.12 & 54.74 & 29.56 \\
R2 (25\%) & 95.71 & 52.59 & 32.56 \\
$\mathbf{R 3}(\mathbf{5 0 \% )}$ & 91.15 & 61.95 & 24.44 \\
\hline
\end{tabular}

The table above shows the composition of the flesh of the Nile tilapia (dry matter, fat, and crude protein) at the beginning and at the end of the experiment.

Value-wise, differences were observed in the body composition of the fish fed on the different diets. The dry matter content of the initial fish (96.33\%) and those of the R1 (94.12\%) and R2 (95.71\%) diets did not differ significantly. On the other hand, these values are higher than that of the value obtained from fish fed on R3 (91.15) regime. The protein content of the flesh was significantly higher in fish fed on R3 diet (61.95\%), followed by those fed on R1 diet (54.74\%) and then R2 diet (52.59\%) compared to that of the initial fish (49, 63\%).

For the fat content, the lowest value was observed from the fish fed with the R3 diet (24.44\%), followed by R1 diet $(29.56 \%)$ and then R2 diet (32.56\%) compared to the initial fish $(41.51 \%)$.

\subsection{Discussion}

During the trial, the mean temperature ranged from 27.50 to $27.80{ }^{\circ} \mathrm{C}$ and it was within the range for best growth performances $\left(24-28^{\circ} \mathrm{C}\right)$. The $\mathrm{pH}$ values recorded (8.74 to 8.75) were also within the range in which Tilapia (O. niloticus) can survive ( 8 to 11$)$ as reported by Balarin and Hatton, 1979.

The fish that received R1 diet containing 0\% crustacean meal and R2 diet containing 25\% crustacean meal had similar weight gain $(0.42 \mathrm{~g})$ but different from that obtained with the R3 diet containing $50 \%$ crustacean meal $(0.36 \mathrm{~g})$. This shows that fishmeal could be partially replaced with crustacean meal (in this case, 25\%) in Nile tilapia feed without any negative effect on the growth. These results are contrary to those of Diop et al. (2013) who reported that the incorporation of shrimp by-products in the diets of tilapia at $45 \%$ gave the best weight gain (4.96 g) compared to the control diet. It is also inconsistent with the results of Fall et al. (2012) who found significant difference between the control and test diets when soybean meal was replaced with shrimp shell meal in the diet of hybrid tilapia. For other fish species, the present result is not in line with the result of Raja Nandini et al. (2014) who achieved 50\% replacement of fishmeal with shrimp waste meal in the diet of Koi carp (Cyprinus carpio haematopterus). 
The best SGR (2.50\% / day) in this study obtained from R1 and the R2 diets is significantly different from the one obtained from R3 diet (2.29\% / day). This is different from the result of Diop et al. (2013) who had the best SGR (3.79\% / day) from tilapia fed with a diet containing $45 \%$ shrimp by-products. It is also inconsistent with the result of Fall et al. (2012) who did not find any significant difference between the control diet and $67 \%$ substitution of shrimp shell meal with soybean meal in the diet of hybrid tilapia. For other fish species, the present result differed from the result of Raja Nandini et al. (2014) who reported that the replacement of fishmeal with shrimp waste meal up to $50 \%$ was significantly better than the control fishmeal based diet for Koi carp (Cyprinus carpio haematopterus). Also, Tibbets et al. (2011) found that the best performance was obtained with $100 \%$ krill meal in both cod and Atlantic halibut.

In this study, the best feed conversion ratio (1.42) was obtained with R3 diet containing 50\% crustacean meal and 50\% fishmeal while R2 diet containing $25 \%$ crustacean meal and $75 \%$ fishmeal produced the worst FCR (2.93). A similar thing was obtained by Diop et al. (2013) who reported the best FCR (1.69) from tilapia fed on diet containing $45 \%$ shrimp by-products compared to that of the control (3.35). Compared to the results obtained from other fish species, the result of the present study is in agreement with that obtained by Raja Nandini $e t$ al. (2014) who observed the best FCR (1.30) in Koi carp fed on diet containing 50\% shrimp waste meal. It is also consistent with that of Keremah (2013) who showed that African giant catfish fed on diet containing $40 \%$ of crab meal had the best feed conversion ratio (1.12) compared to the control diet containing only fishmeal. Toppe et al. (2005) also indicated that cod fed with the highest rate of crab meal had the best FCR compared to other groups of fish. The FCR result of this study is not in line with the result of Fall et al. (2012) who found the best FCR (1.73) from fish fed on the control diet followed by fish fed with the diet containing $25 \%$ shrimp by-products.

The survival percentage obtained in this study varies between 50 to $90 \%$. The R1 diet had the highest survival (90\%) followed by R2 diet ( $85 \%$ ) containing $25 \%$ crustacean meal and then R3 diet (50\%) containing 50\% crustacean meal. The 85 and $90 \%$ survival obtained from fish fed on R2 and R1 diets are considered excellent based on the observations of Sumi et al. (2011) who stated that survival greater than $80 \%$ is excellent in the nursery. The two values are almost in the same range with the one obtained (95\%) by Nwanna (2003) during feeding trials and digestibility studies of evaluating the effect of replacement of fishmeal by shrimp silage meal at different levels: $0,5,10,20,30$, and $40 \%$. The lowest survival $50 \%$ obtained in the fish fed diet R3 containing 50\% of crustacean meal was probably due to high level of chitin, which is not readily digestible.

The protein and lipid contents of the flesh at the beginning and the end of the experiment were used to determine the influence of the diets on the muscle composition of the fish. Studies have shown that exogenous factors (food composition, temperature, oxygen) and endogenous factors (size, sex, stage of sexual maturity) are likely to influence the body composition of the cultured fish species (Hepher, 1990).

The lipid content of the initial fish $(41.51 \%)$ decreased after subjecting them to the 
experimental diets [R1 (29.56\%), R2 (32.56\%) and R3 (24.44\%)]. This could mean that fish subjected to the experimental diets spent much energy during the trial period to cope with the environment conditions of the cultured medium resulting to the reduction of the body lipid. Moreover, the low lipid content of the experimental fish can be caused by poor digestion of the dietary fat in the feeds. Indeed, well digested dietary lipids generally lead to lipid deposition in the muscle. This plays a significant role in the supply of energy from digestion of complex carbohydrates, a role that is more important for fish (Guillaume et al., 1999). The result of this study is contrary to that of Fall et al. (2012) who observed reduction of fat in the flesh of the experimental fish compared to the initial fish. It is also not in line with the result of Diop et al. (2013) who reported that the lipid content of the initial fish (83.73\%) was almost the same as those found in the experimental fish $(85.93 \%, 86.43 \%$, and $87 \%)$.

Fish muscle protein level increased after trial from initial $(49.63 \%)$ to $54.74 \%, 52.59 \%$ and $61.95 \%$ for R1, R2 and R3 respectively. This indicates that the fish were able to convert the dietary protein of the experimental feeds into body protein. This result agrees with that of Fall et al. (2012) who observed an increase in the protein content of the dorsal muscle of the fish when fed on the tested diets compared to the initial fish. Compare to other fish species, the result of the present study is concurrent with that of Nwanna (2003) who also made similar observation when Clarias were fed on the shrimp ensiled head meal.

\section{Conclusion and Perspectives}

Global aquaculture continues to grow and intensify. Reducing the use of fishmeal, the primary source of protein in the diet of farmed fish through substitutions for meeting sustainable development is one of the significant challenges for future aquaculture development worldwide. The present study reveals the importance of crustacean meal as an essential ingredient in tilapia feed.

The results obtained showed the importance of the partial substitution of fishmeal by crustacean meal in the diet of tilapia (Oreochromis niloticus). The fish fed on diet containing $25 \%$ crustacean meal had the same growth performance as those fed on diet containing fishmeal. This shows that crustacean meal can partially replace fishmeal in the tilapia $(O$. niloticus) feed. However, it seems that the higher the incorporation rate of crustacean meal, the lower the growth performance. The results of this experiment showed that crustacean meal could replace $25 \%$ of fishmeal in the diet of tilapia without affecting the nutritional quality of the feed.

The laboratory study should be repeated in ponds where live feeds contribute to the supply of nutrients. Studies focusing on the digestibility of diet containing crustacean meal may complement the results. 


\section{References}

Acad. C. R. Se. Paris, T. 277 (1973). Série D - 513. ZOOLOGIE. Sur la systématique-et la phylogénie des Thalassinidea: définition des familles des Callianassidae et des Upogebiidae et diagnose de cinq genres nouveaux (Crustacea Decapoda), $4 \mathrm{p}$.

Association of Official Analysis Chemists (AOAC) (1984). Official Methods of Analysis, $14^{\text {ed }}$, AOAC Arlington, VA, 1141.

Balarin J. D., \& Hatton J. D. (1979). Tilapia: A guide to their biology and culture in Africa. Unit of Aquatic Pathobiology, Stirling University, 174 p.

Diop, D., Sagne, M., Fall, J., Loum, A., Ndong, D., Diouf, M., ... Thiaw, O. T. (2013). Use of Biochemically Improved Shrimp Industry Waste in Fry Tilapia (Oreochromis niloticus Linnaeus 1758) Diets: Effects on Growth Performance and Carcass Composition. Journal of Biology and Life Science, 4(2), August 2013. https://doi.org/10.5296/jbls.v4i2.4091

El-Sayed, A. M. (1998). Total replacement of fishmeal with animal protein sources in Nile tilapia, Oreochromis niloticus (L.), feeds. Aquac. Res., 29, 275-280. https://doi.org/10.1046/j.1365-2109.1998.00199.x

Fall, J., Tseng, Y. T., Ndong, D., \& Sheen, S. S. (2012). The effects of replacement of soybean meal by shrimp shell meal on the growth of hybrid tilapia (Oreochromis niloticus $\mathrm{x}$ Oreochromis aureus) reared under brackish water. International Journal of Fisheries and Aquaculture, 4, 85-91.

FAO, (2016). Situation mondiale de la pêche et de l'aquaculture, Rome, 227p.

Gill T. A. (2000). Waste from processing aquatic animals and animal products: implications on aquatic animal pathogen transfer. FAO Fisheries Circular, n ${ }^{\circ}$ 956, 26 p.

Guillaume, J., Kaushik, S., Bergot, P., \& Metailler, R. (1999). Nutrition et alimentation des poissons et crustacés. $489 \mathrm{p}$.

Hepher, B. (1990). Nutrition of pond fishes, Cambridge. Cambridge University Press, 388 p.

Jung, W. J., Jo, G. H., Kuk, J. H., Kim, K. Y., \& Park, R. D. (2006). Extraction of chitin from red crab shell waste by cofermentation with Lactobacillus paracasei subsp. tolerans KCTC-3074 and Serratia marcescens FS-3, Microbial and Cell Physiology. Appl Microbiol Biotechnol, 71, 234-237. https://doi.org/10.1007/s00253-005-0126-3

Keremah, R. I. (2013). The effects of replacement of fish-meal with crab-meal on growth and feed utilization of African giant catfish Heterobranchus longifilis fingerlings, 62-64.

Laila, M., Olfa, G. B., Kemel, J., Islem, Y., \& Moncef, N. (2010). Extraction and Characterization of Chitin, Chitosane and Protein Hydrolysates Prepared from Shrimp Waste by Treatment with Crude Protease from Bacillus cereus SVI, Appl Biochem Biotechnol, 162, 345-357. https://doi.org/10.1007/s12010-009-8846-y

Nwanna, L. C. (2003). Nutritional Value and Digestibility of Fermented Shrimp Head Waste 
Meal by African Catfish Clarias gariepinus. Pakistan J. Nutr., 2, 339-345. https://doi.org/10.3923/pjn.2003.339.345

Plascencia-Jatomea, M., Olvera-Novoa, M. A., Arredondo-Figueroa, J. L., Hall, G. M., \& Shirai, K. (2002). Feasibility of fishmeal replacement by shrimp head silage protein hydrolysate in Nile tilapia (Oreochromis niloticus L) diets. J Sci Food Agric, 82, 753-759. https://doi.org/10.1002/jsfa.1092

Raja Nandini, T. P. S., Felicitta, J., Chelladurai, G., \& Nagarajan, R. (2014). The effect of replacement of fish meal by shrimp waste meal (swm) On growth, total carotenoid, and proximate composition of Koi carp (Cyprinus carpio haematopterus), 26-27.

Sumi, K. R., Das, M., \& Siddika, I. (2011). Effect of different protein levels of fry feed on the production of quality tilapia (Oreochromis niloticus) fry. Journal Bangladesh Agriculture. University, 9, 365-374. https://doi.org/10.3329/jbau.v9i2.11053

Tibbets, S. M., Olsen, R. E., \& Lall, S. P. (2011). Effects of partial or total replacement of fish meal with freeze-dried krill (Euphasia superba) on growth and nutrient utilization of juvenile Atlantic cod (Gadus morhua) and Atlantic halibut (Hippoglossus hippoglossus) feed the same practical diets, Aquaculture nutrition, 17, 287-303. https://doi.org/10.1111/j.1365-2095.2010.00753.x

Toppe, J., Aksnes, A., Hope, B., \& Albrektsen, S. (2005). Inclusion of fish bone and crab by-products in diets for Atlantic cod, Gadus morhua.5p.

Uno, K., Chaweepack, T., \& Ruangpan, L. (2010). Pharmacokinetics and bioavailability of oxytetracycline in vannamei shrimp (Penaeus vannamei) and the effect of processing on the residues in muscle and shell, Bangkok 109, Thailand Aquacult Int, 18, 1003-1015. https://doi.org/10.1007/s10499-009-9318-7

Wenhong, C., Chaohua, Z., Pengzhi, H., \& Hongwu, J. (2008). Response surface methodology for autolysis parameters optimization of shrimp head and amine acids released during autolysis, Food Chemistry Elsevier. 109(1), 176-183. https://doi.org/10.1016/j.foodchem.2007.11.080

\section{Copyright Disclaimer}

Copyright for this article is retained by the author(s), with first publication rights granted to the journal.

This is an open-access article distributed under the terms and conditions of the Creative Commons Attribution license (http://creativecommons.org/licenses/by/4.0/). 